\title{
SEISMIC STRENGTHENING OF PLAN IRREGULAR RC BUILDINGS WITH RE-ENTRANT CORNERS USING SHEARWALLS
}

\author{
P Sanketh ${ }^{1}$, B D V Chandra Mohan Rao ${ }^{2}$ \\ ${ }^{1}$ PG Student, Dept. of Civil Engineering, VNR Vigninana Jyothi Institute of Engineering and Technology, \\ Hyderabad, Telangana 500090, India \\ sanketh.civil@gmail.com \\ ${ }^{2}$ Professor, Dept. of Civil Engineering, VNR Vigninana Jyothi Institute of Engineering and Technology, \\ Hyderabad, Telangana 500090, India \\ bdvcmrao@gmail.com
}

\begin{abstract}
The seismic behavior of buildings critically depends on its overall size, shape and configuration. Buildings with re-entrant corners in plan are considered to be irregular by many seismic design codes. Of the various irregular shaped buildings, $H$-shape is one of the most vulnerable and commonly used floor plans with re-entrant corners. The seismic behavior of RC buildings $(H-$ shape) with symmetrical floor plan having re-entrant corners with shear wall as seismic resisting element is investigated in this paper. Various types of building plan configurations with shear walls at different locations are studied. These buildings are modeled and analyzed using ETABS 2015 software. A building without shear wall is also modeled as a bench mark problem to compare all other models with this. Time history analysis has been carried out for all these models located in Vijayawada. Bhuj earthquake ground acceleration data recorded at Ahmedabad station is given as input acceleration for time history analysis. Various dynamic response parameters such as Story displacement, Story drift are compared and some useful conclusions are drawn.
\end{abstract}

Keywords : Irregular Buildings, Re-Entrant Corners, Floor Plan Shape, Shear Wall, Dynamic Response Parameters. *** $*$

\section{INTRODUCTION}

The buildings that have been significantly damaged during past earthquakes have shown that the dynamic behavior of structures is affected to a great extent by its shape, dimensions and location of structural elements. The architectural issues are often relied on structural demand to design earthquake resistant buildings. Many codes on seismic design identify various types of irregularities and provide specifications regarding building configurations. Presence of re-entrant corners in floor plan is one such irregularity. But these type of building configurations give functional, ventilation and spatial advantages. Irregular floor plan shapes (such as $\mathrm{H},+, \mathrm{C}, \mathrm{L}$ ) are common for public buildings (such as hotels, schools, hostels, apartments) in urban areas because they provide more no. of perimeter rooms with proper ventilation as well as open areas which can be used as parks, play grounds, assembly areas.

As per IS 1893, re-entrant corner irregularity shall be considered where both projections of the structure beyond the re-entrant corner are greater than 15 percent of its plan dimension in the given direction. In the present study seismic behavior of various buildings of $\mathrm{H}$-shaped plan with shear walls at different locations is compared with building having no shear walls. The A/L ratio (0.33) is kept same in both $\mathrm{X}$ and $\mathrm{Y}$ directions. All the buildings are analyzed by linear time history method with Bhuj earthquake (2001) acceleration data recorded at Ahmadabad station as input. The modeling and analysis of these buildings has been carried out using ETABS 2015 software.

\section{LITERATURE REVIEW}

Christopher Arnold (2006) discussed the basic seismic structural systems in relation to architectural configurations. He observed that many common and useful architectural forms are in conflict with seismic design needs. The ultimate solution to these conflicts depends on the architect and engineer working together on building design from the outset of the project and engaging in knowledgeable negotiation.

L.T.Guevara, J.L.Alonso, E.Fortoul (1992) studied the influence of floor plan shape on the response of buildings to earthquakes. They performed dynamic analysis to study torsional effects in buildings with different plan configurations.

Govind M, Kiran K. Shetty, K. Anil Hegde (2014) carried out seismic evaluation of high rise regular and irregular structures using pushover analysis. They concluded that the plan configurations of structure is having significant impact on the seismic response in terms of displacement and base shear. 
Divyashree M, Gopi Siddappa (2014) studied seismic behaviour of RC Buildings with re-entrant corners and strengthening. An improvement in base shear carrying capacity and roof drift capacity of the frames is observed by the introduction of retrofitting methodologies and also concluded that the frames with re-entrant corners showed poor performance.

Divyashree M, Bhavyashree B N, Gopi Siddappa (2014) compared bracings and shear walls as seismic strengthening methods to buildings with plan irregularities. Reduction in roof top displacement is observed with the increase in the stiffness of the strengthening elements in their study.

\section{MODELING AND ANALYSIS}

In this research work, 10 storied buildings with different plans containing re-entrant corners are modeled and analyzed by ETABS v 15 and the results are compared with that of the regular plan building. All building plans have equal dimensions and same $\mathrm{A} / \mathrm{L}$ ratios in $\mathrm{X} \& \mathrm{Y}$ directions with approximately same floor areas and lateral strengths. Preliminary design has been carried out to arrive at the appropriate dimensions of various members. The geometry, loads and other specifications of all buildings are as given below.

\subsection{General Specifications}

- No of bays in X direction : 6

- Grade of Concrete : M 30

- Height of each storey : $3 \mathrm{~m}$

- Live load on floors : $4 \mathrm{kN} / \mathrm{m}^{2}$

- Floor Finishes : $1 \mathrm{kN} / \mathrm{m}^{2}$

- Beam size : $300 \mathrm{~mm}$ x $700 \mathrm{~mm}$

- Slab thickness : $150 \mathrm{~mm}$

- Soil Types : Type II (Medium Soil)

- Damping : $5 \%$ (RC building)

\author{
No of bays in Y direction : 6 \\ Grade of Steel : Fe 415 \\ Number of storeys : 10 \\ Live load on roof : $1.5 \mathrm{kN} / \mathrm{m}^{2}$ \\ Wall Load : $13.8 \mathrm{kN} / \mathrm{m}(230 \mathrm{~mm})$ \\ Column size : $650 \mathrm{~mm}$ x $650 \mathrm{~mm}$ \\ Shear wall thickness : $250 \mathrm{~mm}$ \\ Importance factor : 1.5
}

The buildings are represented as shown below:

H1 : Building without shear wall (shown in Fig. 1)

$\mathrm{H} 2$ : Building with shear walls on outer sides (shown in Fig. 2)

$\mathrm{H} 3$ : Building with shear walls on outer sides (shown in Fig. 3)

$\mathrm{H} 4$ : Building with shear walls on outer side in Y and inner side in X dir. (shown in Fig. 4)

H5 : Building with shear walls on inside corners (shown in Fig.5)

H6 : Building with shear walls on inside corners (shown in Fig.6)

H7 : Building with shear walls on outside corners (shown in Fig.7)

H8 : Building with shear walls on inner sides (shown in Fig.8)

H9 : Building with shear walls on inner sides (shown in Fig.9)

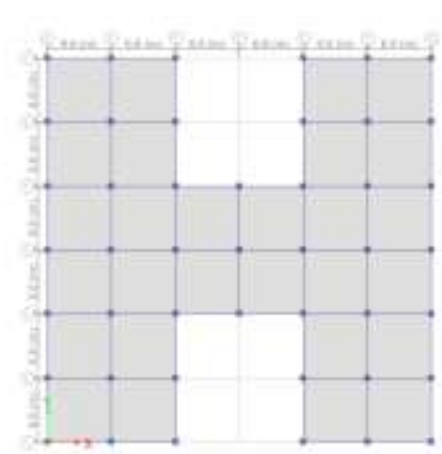

Fig. 1 : H1

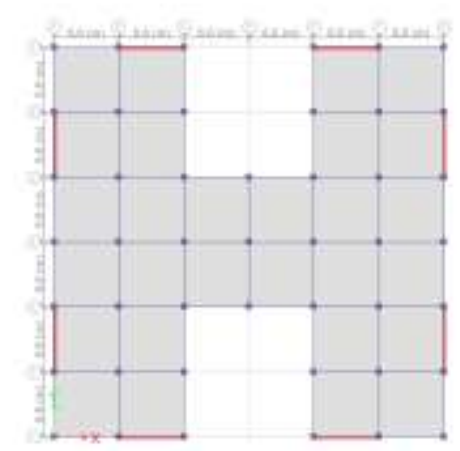

Fig. 2 : H2

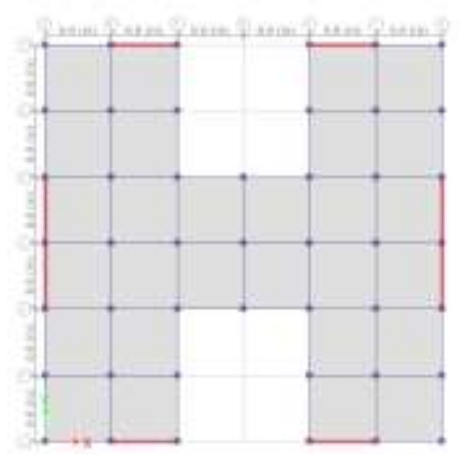

Fig. 3 : H3 


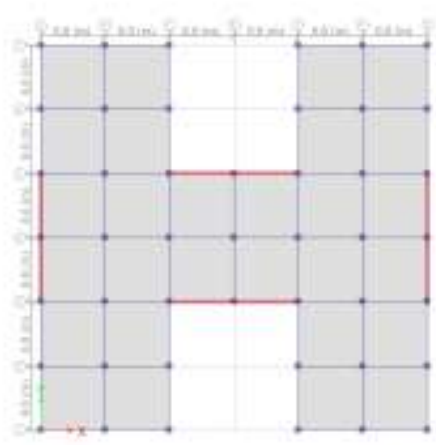

Fig. 4 : H4

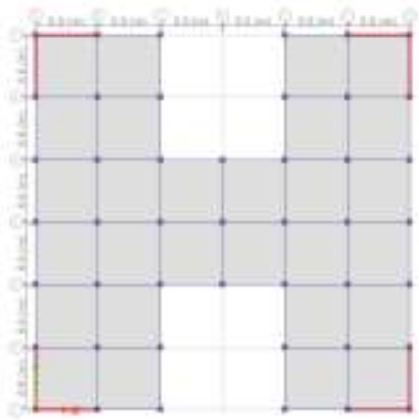

Fig. 7 : $\mathbf{H 7}$

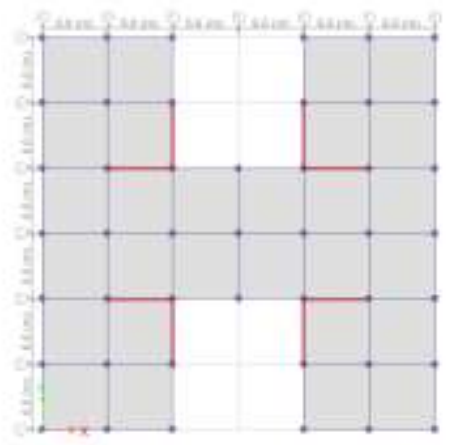

Fig. 5 : $\mathrm{H5}$

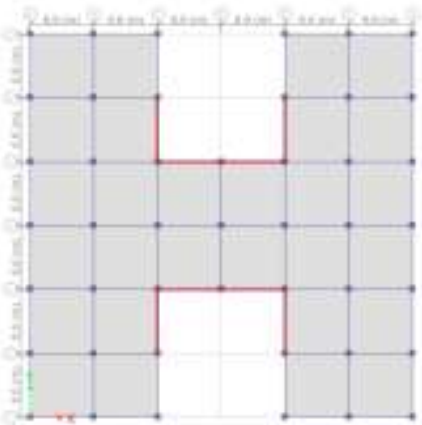

Fig. 8 : $\mathrm{H8}$

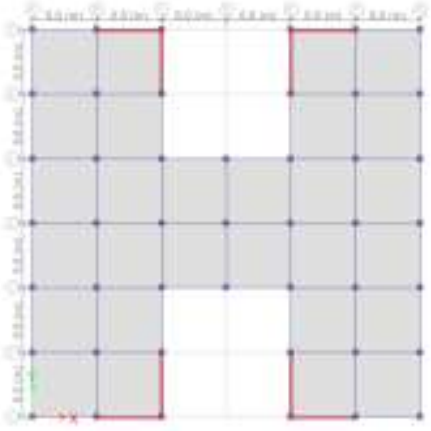

Fig. 6 : $\mathrm{H6}$

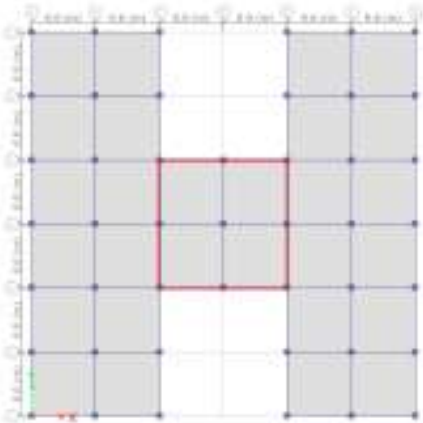

Fig. 9 : H9

Figures 1 to 9 : Plan configurations of different models

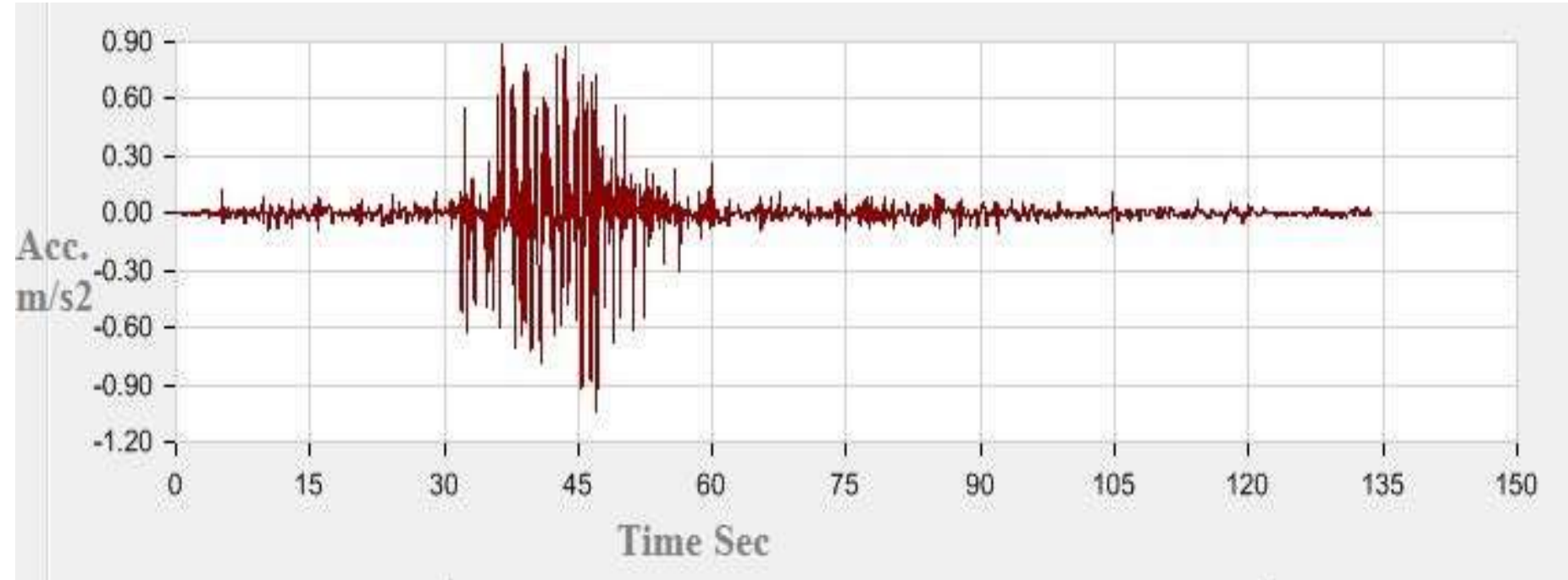

Fig 10. Ground Acceleration of Bhuj Earthquake (2001) at Ahmadabad

\section{RESULTS AND DISCUSSION}

The results of time history analysis in the form of maximum storey displacements and maximum storey drifts at peak response acceleration were studied. The values of maximum storey displacements of different models at peak response are shown in Table 1 and their variation is shown in Fig. 11. The values of maximum storey drift ratios of different models at peak response are shown in Table 2 and their variation is shown in Fig. 12 
Table 1 : Maximum Storey Displacements of Different Models

\begin{tabular}{|c|c|c|c|c|}
\hline \multirow{2}{*}{ Model id. } & \multicolumn{4}{|c|}{ Storey Displacement (mm) } \\
\cline { 2 - 5 } & EQ-X & \% Variation & EQ-Y & \% Variation \\
\hline H1 & 701.6 & & 799.3 & \\
\hline H2 & 527.1 & 24.87 & 372.5 & 53.39 \\
\hline H3 & 529.6 & 24.51 & 322.7 & 59.62 \\
\hline H4 & 322.2 & 54.07 & 322.7 & 59.62 \\
\hline H5 & 266.4 & 62.02 & 273 & 65.84 \\
\hline H6 & 249.8 & 64.39 & 261.1 & 67.33 \\
\hline H7 & 249.6 & 64.42 & 260.9 & 67.35 \\
\hline H8 & 92.2 & 86.85 & 272.1 & 65.95 \\
\hline H9 & 96.8 & 86.20 & 97.1 & 87.85 \\
\hline
\end{tabular}

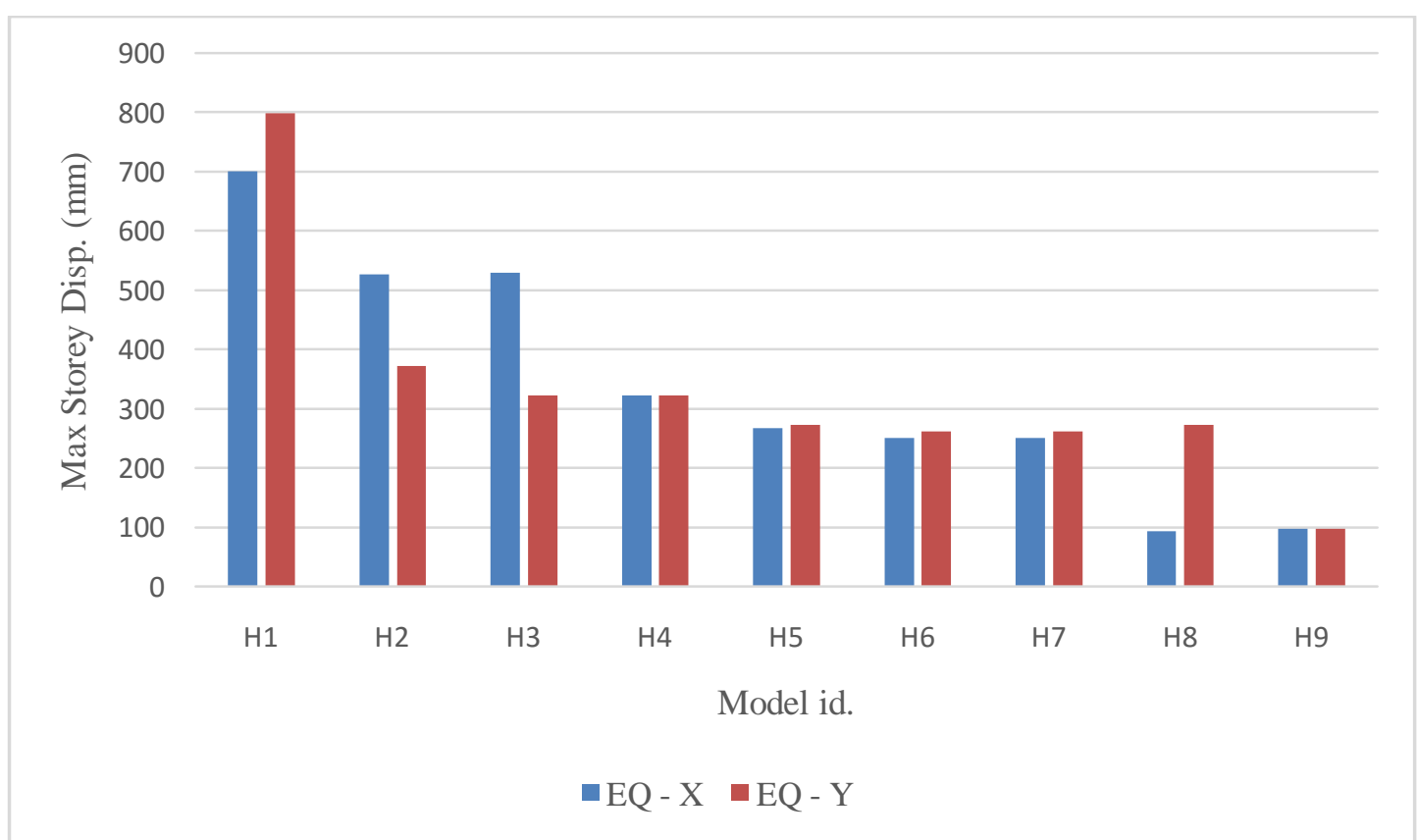

Fig. 11 : Variation of Maximum Storey Displacements of all Models

Table 2 : Maximum Storey Drift Ratios of Different Models

\begin{tabular}{|c|c|c|c|c|}
\hline \multirow{2}{*}{ Model id. } & \multicolumn{4}{|c|}{ Storey Drift Ratio } \\
\cline { 2 - 5 } & EQ-X & \% Variation & EQ-Y & \% Variation \\
\hline H1 & 0.033506 & & 0.039278 & \\
\hline H2 & 0.021932 & 34.54 & 0.015342 & 60.93 \\
\hline H3 & 0.022043 & 34.21 & 0.01279 & 67.43 \\
\hline H4 & 0.012857 & 61.62 & 0.012878 & 67.21 \\
\hline H5 & 0.010673 & 68.14 & 0.010954 & 72.11 \\
\hline H6 & 0.009968 & 70.25 & 0.010445 & 73.40 \\
\hline H7 & 0.009957 & 70.28 & 0.010437 & 73.42 \\
\hline H8 & 0.003484 & 89.60 & 0.010918 & 72.20 \\
\hline H9 & 0.003752 & 88.80 & 0.00376 & 90.42 \\
\hline
\end{tabular}




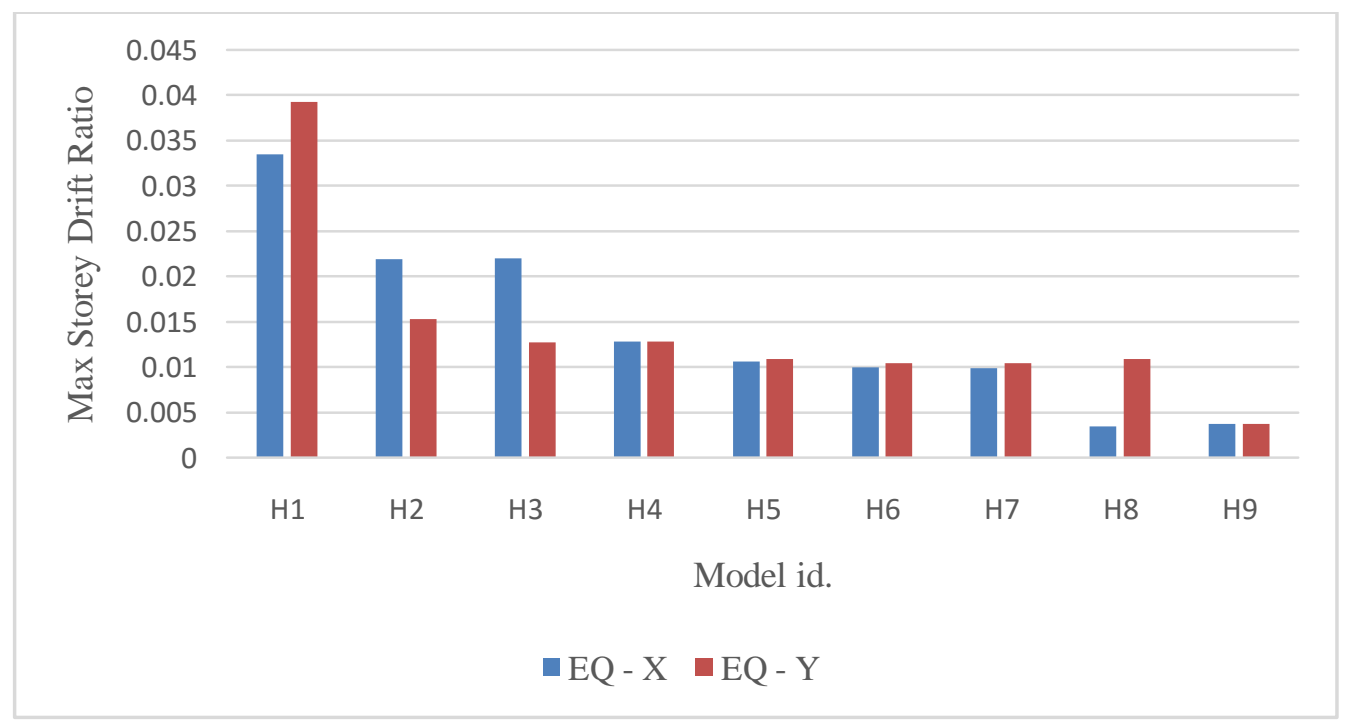

Fig. 12 : Variation of Maximum Storey Displacements of all Models

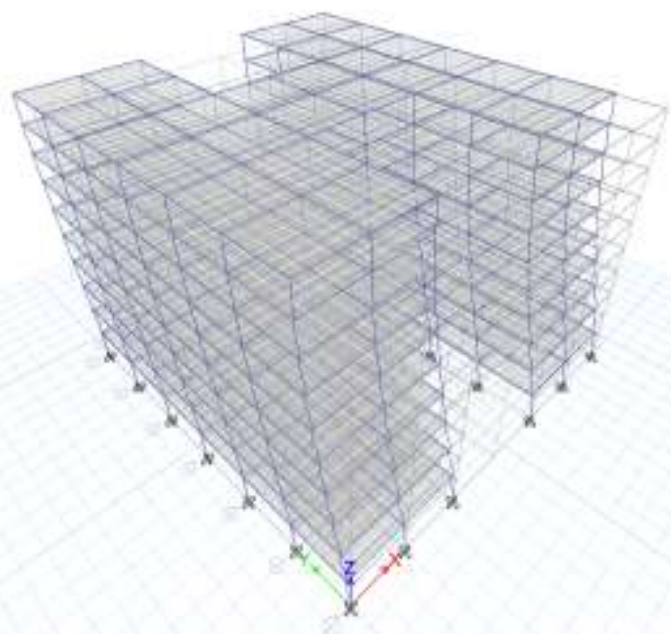

Fig.13 : Deformed Shape of H1 Model

\subsection{Maximum Storey Displacement}

For buildings with shear walls on outside perimeter i.e, in Models $\mathrm{H} 2$ and $\mathrm{H} 3$, the maximum storey displacement with respect to building without shear walls has decreased by $25 \%$ \& $24 \%$ in $\mathrm{X}$ direction and $53 \%$ \& $59 \%$ in $\mathrm{Y}$ direction respectively.

> For building with shear walls on outer side in Y direction and on inner side in $\mathrm{X}$ direction i.e, in Model $\mathrm{H} 4$, the maximum storey displacement with respect to building without shear walls has decreased by $54 \%$ in $\mathrm{X}$ direction and $59 \%$ in $\mathrm{Y}$ direction.

> For building with shear walls on inside corners i.e, in Models H5 and H6, the maximum storey displacement w.r.t building without shear walls has decreased by 62 $\%$ \& $64 \%$ in $\mathrm{X}$ direction and $65 \%$ and $67 \%$ in $\mathrm{Y}$ direction respectively.

For building with shear walls on outside corners i.e, in Model H7, the maximum storey displacement wr.t.

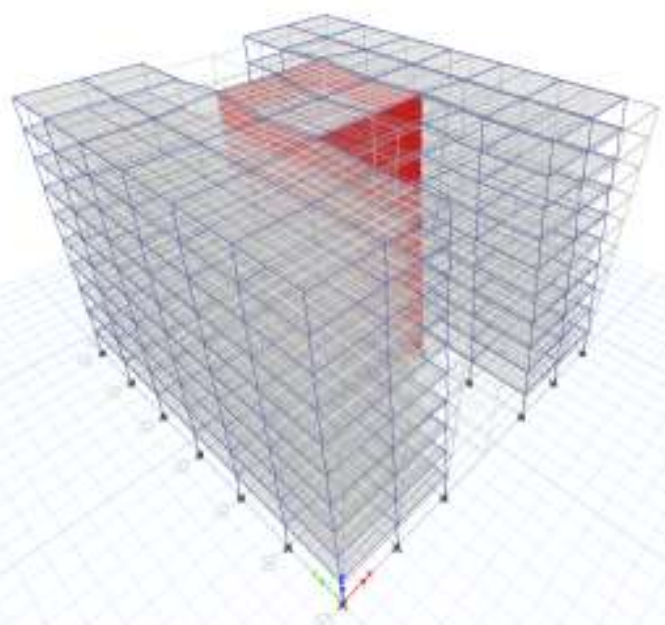

Fig.14 : Deformed Shape of H9 Model

building without shear walls has decreased by $64 \%$ in $\mathrm{X}$ direction and $67 \%$ in Y direction.

$>$ For building with shear walls on inner sides towards centre i.e, in Models H8 and H9, the maximum storey displacement w.r.t building without shear walls has decreased by $87 \%$ \& $86 \%$ in X direction and $66 \%$ and $88 \%$ in $\mathrm{Y}$ direction respectively.

\subsection{Maximum Storey Drift Ratio}

For buildings with shear walls on outside perimeter i.e, in Models $\mathrm{H} 2$ and $\mathrm{H} 3$, the maximum storey drift ratio with respect to building without shear walls has decreased by $34 \%$ \& $34 \%$ in $\mathrm{X}$ direction and $61 \%$ \& $67 \%$ in Y direction respectively.

$>$ For building with shear walls on outer side in $\mathrm{Y}$ direction and on inner side in $\mathrm{X}$ direction i.e, in Model $\mathrm{H} 4$, the maximum storey drift ratio with respect to building without shear walls has decreased by $61 \%$ in $\mathrm{X}$ direction and $67 \%$ in $\mathrm{Y}$ direction. 
For building with shear walls on inside corners i.e, in Models $\mathrm{H} 5$ and H6, the maximum storey drift ratio w.r.t building without shear walls has decreased by $68 \%$ \& $70 \%$ in $\mathrm{X}$ direction and $72 \%$ and $73 \%$ in $\mathrm{Y}$ direction respectively.

$>$ For building with shear walls on outside corners i.e, in Model H7, the maximum storey drift ratio w.r.t. building without shear walls has decreased by $70 \%$ in $\mathrm{X}$ direction and $73 \%$ in $\mathrm{Y}$ direction.

$>$ For building with shear walls on inner sides towards centre i.e, in Models $\mathrm{H} 8$ and $\mathrm{H} 9$, the maximum storey drift ratio w.r.t building without shear walls has decreased by $89 \%$ \& $88 \%$ in $\mathrm{X}$ direction and $72 \%$ and $90 \%$ in $\mathrm{Y}$ direction respectively.

\section{CONCLUSIONS}

* It is concluded that all buildings with shear walls have shown significant decrease in maximum storey displacement and maximum storey drift ratio compared to building without shear walls.

* It is observed that the strengthening of corner walls will have more effect in reducing the dynamic response parameters than strengthening of side walls.

* It is inferred that response parameters of the structure decreases significantly as the shear wall location is closer to center of mass of the building.

\section{REFERENCES}

[1]. IS 1893 (part 1) (2002). Criteria for Earthquake Resistant Design of Structure, B.I.S., New Delhi.

[2]. CSI Analysis Reference Manual for ETABS (2015), Computers \& Structure Inc., 1978-2015, Berkeley, California, USA.

[3]. Christopher Arnold (2006), Seismic Issues in Architectural Design, Chapter 5, Design for Earthquakes A Manual for Architects, FEMA 454.

[4]. L.T.Guevara, J.L.Alonso and E.Fortoul (1992), Floorplan shape influence on the response to earthquakes, Earthquake Engineering, Tenth World Conference, Balkema, Rotterdam, ISBN 9054100605.

[5]. Govind M, Kiran K. Shetty and K. Anil Hegde (2014), Seismic Evaluation of High Rise Regular and Irregular Structure Using Pushover Analysis, IOSR Journal of Mechanical and Civil Engineering, e-ISSN: 2278-1684, pISSN: 2320-332X, PP 14-19.

[6]. Divyashree $M$ and Gopi Siddappa (2014), Seismic Behavior of RC Buildings with Re-entrant Corners and Strengthening, IOSR Journal of Mechanical and Civil Engineering, e-ISSN: 2278-1684, p-ISSN: 2320-334X, PP 63-69.

[7]. Divyashree M, Bhavyashree B N and Gopi Siddappa (2014), Comparison of Bracings and Shear Walls as Seismic Strengthening Methods to Buildings with Plan Irregularities, IJRET: International Journal of Research in Engineering and Technology, e-ISSN: 2319-1163, p-ISSN: 2321-7308. 